http://kitaibelia.unideb.hu/

ISSN 2064-4507 (Online) • ISSN 1219-9672 (Print)

(C) 2016, Department of Botany, University of Debrecen, Hungary

22 (1): 71-76.; 2017

DOI: $10.17542 /$ kit. 22.71

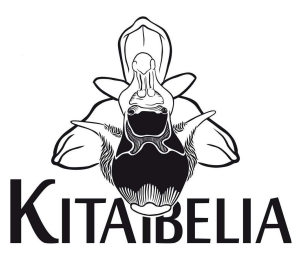

\title{
A Vaccinium microcarpum (Turcz. ex Rupr.) Schmalh. Magyarországon
}

\author{
NAGY János György ${ }^{1 *}$, ZSINKA Bernadett², VEREBÉLYI Viktória², \\ ZORKóCZY Orsolya Krisztina ${ }^{2} \&$ TYLER Teadora ${ }^{2}$
}

(1) Szent István Egyetem MKK Növénytani és Ökofizológiai Intézet, H-2100 Gödöllő, Páter Károly utca 1.; *nagyjano@yahoo.com

(2) Állatorvostudományi Egyetem, Biológia Intézet, H-1077 Budapest, Rottenbiller u. 50.

Vaccinium microcarpum (Turcz. ex Rupr.) Schmalh. in Hungary

\begin{abstract}
The plant that was reported as Vaccinium oxycoccos L. from the Nyírjes-tó (Sirok village, NE Hungary) in 1994 was subsequently (1999) identified as Vaccinium microcarpum (Turcz. ex Rupr.) Schmalh. by the first author of this article. To substantiate this identification morphometric data were collected and analysed from Vaccinium specimens occurring in the Sphagnum dominated mires of Nyírjes-tó (Sirok vilage) and Nyíres-tó as well as Báb-tava (Bereg-plain) in September 2016. Field photographs taken previously at the localities of Bereg-plain were also used for identification. The leaves of the Sirok plants are smaller, ovate-triangular, i.e. widest near base. The ovate-elliptic bracteoles are inserted on the basal third of the glabrous pedicels. The flowers are solitary, and have dark pink corollas and hairy filaments on the whole abaxial surface. The fruit is pyriform. In contrast to the Sirok plants, those of the Bereg-mires have clearly larger and ovate-elliptic leaves. The filiform bracteoles are inserted on the middle third of the minutely hairy pedicels. The whitish flowers are grouped in clusters of (2)-3-4-(5), i.e. they form an inflorescence. The filaments are hairy only on the margins of the abaxial surface. The fruit is globular. The statistical analysis confirmed that the Sirok plants belong to $V$. microcarpum, whereas the Bereg-plain plants represent $V$. oxycoccos.
\end{abstract}

Keywords: Bereg mires, flora of Hungary, Nyírjes-tó mire at Sirok, Sphagnum dominated mire, Vaccinium oxycoccos

Összefoglalás - A növényt, amelyet 1994-ben Vaccinium oxycoccos L. néven közöltek a Siroki Nyírjestóról, e cikk első szerzője 1999-ben Vaccinium microcarpum (Turcz. ex Rupr.) Schmalh. fajként azonosította. A határozás helyességét bizonyító morfometriai tulajdonságok gyüjtésére 2016. augusztus 24-én került sor a siroki Nyírjes-tó tőzegmohalápján és szeptember 2-án és 3-án a beregi Báb-tava és a Nyíres-tó tőzegmohalápján. A vizsgálatokhoz felhasználtuk a Beregi-lápokon készített korábbi saját fényképfelvételeinket is. A siroki állomány növényeinek apró, háromszög-tojásdad alakú levelei a levélvállnál a legszélesebbek, a tojásdad-elliptikus murvák a csupasz virágkocsányok alsó harmadában fejlődnek, sötét rózsaszín virágaik magánosak, a porzószálak abaxiális felülete mindenütt szőrős, és a termés körte alakú. A beregi állomány növényeinek ezzel szemben elliptikus-tojásdad levelei szélességében és hosszúságában is jóval nagyobbak. Szőrös virágkocsányaik középső harmadában fejlődnek a szálas-lándzsás murvák, fehér virágaik (2)-3-4-(5) virágú virágzatot alkottak, a porzószálaknak csak a szélei szőrösek, a termés gömb alakú. A. A gyüjtött adatok statisztikai elemzése alátámasztotta, hogy a Sirokon található növények V. microcarpum fajhoz, míg a beregiek $V$. oxycoccos fajhoz tartoznak.

Kulcsszavak: Beregi-lápok, Magyarország flórája, Siroki Nyírjes-tó, tőzegmohaláp, Vaccinium oxycoccos 


\section{Bevezetés}

A tőzegáfonyát (Vaccinium oxycoccos agg.) a Trianon utáni Magyarországról először SimoN (1953, 1954, 1960) jelezte a Beregi-sík három lápjáról (Nyíres-tó, Báb-tava, Navad-patak). A növényt Szurdoki Erzsébet, Kröel-Dulay György, Rédei Tamás és Barabás Sándor 1994-ben a siroki Nyírjes-tavon is megtalálta, az addig a területről szintén ismeretlen kereklevelű harmatfüvel (Drosera rotundifolia L.) együtt (SZURDOKI 2005). A lápott megtaláló és annak flóráját és vegetációját részletesen bemutató Kovács Margit a növényt nem közölte a területről (MÁTHÉ \& KovÁcS 1958) és nem is látta (Kovács ex verbis). A faj előfordulása a nyírjes-tavi fúrásminták makrofoszíliáinak vizsgálatai során sem került elő (JAKAB \& SÜMEGI 2010). SZMORAD \& BARABÁS (1999) szerint nyírjes-tavi jelenléte bizonytalan eredetű, elképzelhető, hogy betelepítés eredménye.

Nagy János 1999 nyarán a számos irodalmi forrás (LÁJER 1998, BARTHA 1999, FARKAS 1999, SZMORAD \& BARABÁS 1999, Simon 2000, SzuRdoKi 2005, LÁjER 2009) által akkor és azóta is Vaccinium oxycoccos L. néven ismertett növényt Vaccinium microcarpum (Turcz. ex Rupr.) Schmalh. fajként azonosította. Tőle függetlenül Molnár V. $(2007,2008)$ a siroki növény esetében valószínúsítette az új megtelepedést és azt is, hogy az a Beregi-síkon található fajjal nem azonos, azaz „a két hazai állomány úgy tûnik, hogy két különböző alakként értékelhető”.

Közleményünk célja, hogy a két hazai állományban végzett morfometriai méréseink elemzésével jellemezzük a Vaccinium microcarpum (Turcz. ex Rupr.) Schmalh. és Vaccinium oxycoccos L. fajokat.

\section{Anyag és módszer}

Az alaktani tulajdonságok gyűjtésére a siroki Nyírjes-tó tőzegmohalápján 2016. augusztus 24-én, a beregi Báb-tava és Nyíres-tó tőzegmohalápjain 2016, szeptember 2-án és 3-án került sor. 50-50 levél szélességét és hosszúságát mértük mindkét állomány különböző egyedein. A siroki állomány gyenge másodvirágzásban volt, itt mindössze 7 virágzó-, egy bimbósvalamint egyetlen terméses hajtást találtunk. A beregi állományban virágzó egyedet nem, csak terméseset találtunk, a Báb-taván 5-öt, a Nyíres-tavon 20-nál is többet. Megmértük a virágos és terméses kocsányok alapjától az alsó murvalevél eredéséig tartó hosszát és megmértük a kocsánynak az alaptól a vacokig tartó (teljes) hosszát. A murvalevél pozíciójának bemutatásához pedig a kettő hányadosát képeztük. A siroki lápon 9 (7 virágzó, egy bimbós és egy terméses), a beregi két lápon 7 terméses kocsányt mértünk meg. Feljegyeztük a lomblevelek-, a murvák- és a termések alakját, a kocsányok és a porzószálak szőrözöttségét, a szirmok színét, a termések alakját. A méréseket a levelek és a kocsányok esetében szkennelés után az ImageJ programmal végeztük. A két alakot bemutató rajzok az eredeti növények alapján készültek. Megállapításainkhoz felhasználtuk a Beregi-lápokon készített korábbi saját fényképfelvételeinket is.

A taxonok magyar elnevezéséhez a hazai irodalom (JÁvORKA 1924-25, SiMON 2000, LÁJER 2009.) mellett a latin, angol és orosz irodalmakban használt neveket vettük alapul.

\section{Eredmények és értékelésük}

A két vizsgált állomány egyedei több jellegzetességükben jelentősen eltérnek egymástól (1. táblázat, 1. ábra). 
1. táblázat. A siroki és a beregi tőzegáfonya állományok egyes jellemzőinek összehasonlítása Table 1. Comparison of some characters of the Sirok and Bereg cranberry populations

\begin{tabular}{|c|c|c|}
\hline & Siroki állomány & Beregi állományok \\
\hline Lomblevél alakja & $\begin{array}{c}\text { Háromszög-tojásdad alakú. } \\
\text { Leggyakrabban a lekerekített } \\
\text { levélvállnál, vagy közvetlenül fölötte a } \\
\text { legszélesebb. (2.ábra, Dvm) }\end{array}$ & $\begin{array}{c}\text { Általában tojásdad, ritkábban } \\
\text { elliptikus alakú. } \\
\text { (2. ábra, Dvo) }\end{array}$ \\
\hline 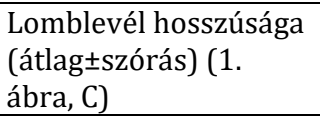 & $5,21 \pm 0,76 \mathrm{~mm}$ & $10.8 \pm 0.96 \mathrm{~mm}$ \\
\hline 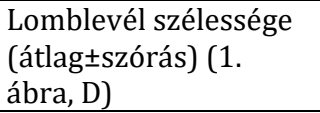 & $1,55 \pm 0,24 \mathrm{~mm}$ & $4.65 \pm 0.57 \mathrm{~mm}$ \\
\hline Kocsány szőrözöttsége & Kopasz (2. ábra, $A_{V m}$ ) & Szőrös (2.ábra, $A_{v_{0}}$ ) \\
\hline $\begin{array}{l}\text { Murvalevél } \\
\text { elhelyezkedése }\end{array}$ & $\begin{array}{c}\text { általában a kocsány alsó harmadában } \\
\left.\text { (2. ábra, } A_{V m}\right)\end{array}$ & $\begin{array}{l}\text { a kocsány középső harmadában } \\
\left(2 . \text { ábra, } A_{v_{0}}\right)\end{array}$ \\
\hline Murvalevél alakja & $\begin{array}{l}\text { tojásdad vagy széles elliptikus } \\
\left(2 \text { ábra, } B_{V m}\right)\end{array}$ & $\begin{array}{l}\text { fonálszerű, szálas } \\
\left.\text { (2. ábra, } A_{v_{0}}\right)\end{array}$ \\
\hline $\begin{array}{l}\text { Virágok száma a } \\
\text { virágzatban }\end{array}$ & magányos (2. ábra, $A_{V m}$ ) & (1)-3-4-(5) virágú (2. ábra, Avo) \\
\hline Sziromlevelek színe & rózsaszín & fehér, vagy kissé rózsaszínes fehér \\
\hline Porzószál & $\begin{array}{l}\text { Az éleken és az abaxiális lapokon } \\
\text { szőrös. A porzószál sokkal rövidebb, } \\
\text { mint a portok (a tubulusokkal). } \\
\left.\text { (2. ábra, } C_{V m}\right)\end{array}$ & $\begin{array}{c}\text { Éleken szőrös, abaxiális lapokon } \\
\text { kopasz. A porzószál kb. olyan } \\
\text { hosszú, mint a portok (a } \\
\text { tubulusokkal). } \\
\left.\text { (2. ábra, } \mathrm{CV}_{\mathrm{v}}\right) \\
\end{array}$ \\
\hline Termés & $\begin{array}{l}\text { Alapja felé keskenyedő, körte alakú. } \\
\left(2 . \text { ábra, } E_{V m}\right)\end{array}$ & $\begin{array}{c}\text { Nagyjából gömb alakú } \\
\left(2 . \text { ábra, } \mathrm{Ev}_{\mathrm{v}}\right)\end{array}$ \\
\hline
\end{tabular}

Méréseink eredményeinek és SUDA \& LYSHK (2001) munkájának összevetése alapján a siroki növényeket a Vaccinium microcarpum (Turcz. ex Rupr.) Schmalh. fajhoz tartozónak ítéljük, míg a beregi lápok növényeit mi is Vaccinium oxycoccos L.-ként értékeljük (2. ábra).

A két faj elkülönítésére szolgáló határozókulcsot POPOVA (1972), JACQUEMART (1997), KRASNOBOROVA (2000), SUDA \& LYSHK (2001) és ECKEHART (2009) munkája, valamint saját megfigyeléseink és méréseink alapján a következőképpen adjuk közre:

1a. A lomblevelek háromszög-tojásdadok, rendszerint közvetlenül a válluk felett a legszélesebbek, 7 mm-nél rövidebbek: (3)-4-6-(7) mm hosszúak és 2,5 mm-nél keskenyebbek: 12 mm szélesek. A hajtások és a virágkocsányok kopaszak, a virágok rendszerint magányosak (vagy nagyon ritkán, maximum 3 virágú sátor virágzatba tömörülnek). A murvalevelek tojásdadok, kopaszak rendszerint a kocsányok alsó harmadában helyezkedek el. A szirmok (sötét) rózsaszínek, 7 mm-nél rövidebbek: (3)-4-6-(7) mm hosszúak és 2,5 mm-nél keskenyebbek: 1-2,3 mm szélesek. A porzók rövidebbek, mint $4 \mathrm{~mm}$. A porzószálak minden oldala szőrös. A portokok a tubulusokkal együtt legalább 1,5-szer hosszabbak a porzószálaknál. A bibeszálak hossza legfeljebb $5 \mathrm{~mm}$. Az álbogyók gyakran a kocsány felé keskenyedők, vagy megnyúltak, körte vagy citrom alakúak. A magvak nagyon aprók, maximum 1,7 × 0,8 mm-esek. A növény diploid, 2 n=24. ÉK (Mátra: Siroki Nyírjes-tó), valószínűleg az 1990-es évek elején telepítették be.

Vaccinium microcarpum (Turcz. ex Rupr.) Schmalh. - Apró tőzegáfonya

1b. A lomblevelek tojásdad-elliptikusak, 8 mm-nél hosszabbak: (8)-10-12-(14) mm hosszúak és 3 mm-nél szélesebbek: (3)-4-5-(6) mm szélesek. A fiatal hajtások és a virágkocsányok - legalább a virágzás kezdetén - szőrösek. A murvalevelek szálasak és szőrösek, 
rendszerint a kocsány középső vagy felső harmadában helyezkednek el. A törpecserjén mindig találunk 3 vagy több virágból álló virágzatokat. A szirmok (rózsaszínes) fehérek, hosszuk legalább 5,5 mm. A porzók hosszabbak, mint $4 \mathrm{~mm}$. A porzószálaknak rendszerint csak a szélei szőrösek. A portokok a tubulusokkal együtt rendszerint nem, vagy legfeljebb 1,3-szer hosszabbak a porzószálaknál. A bibeszálak $5 \mathrm{~mm}$-nél hosszabbak. Az álbogyók gömb, vagy kissé lapított gömb alakúak. A magvak rendszerint 1,7 × 0,8 mm-nél nagyobbak. A növény tetra-, penta-, vagy hexaploid: 2n=48, 60, 72. ÉA (Csaroda-Beregdaróc: Navad-patak†, Nyíres-tó, Báb-tava; FARKAS (1999) adata a gelénesi Zsid-tóról minden bizonnyal téves), NyDt (Zalai-dv.: Vindornyai-láp)†.

Vaccinium oxycoccos L. - Közönséges tőzegáfonya
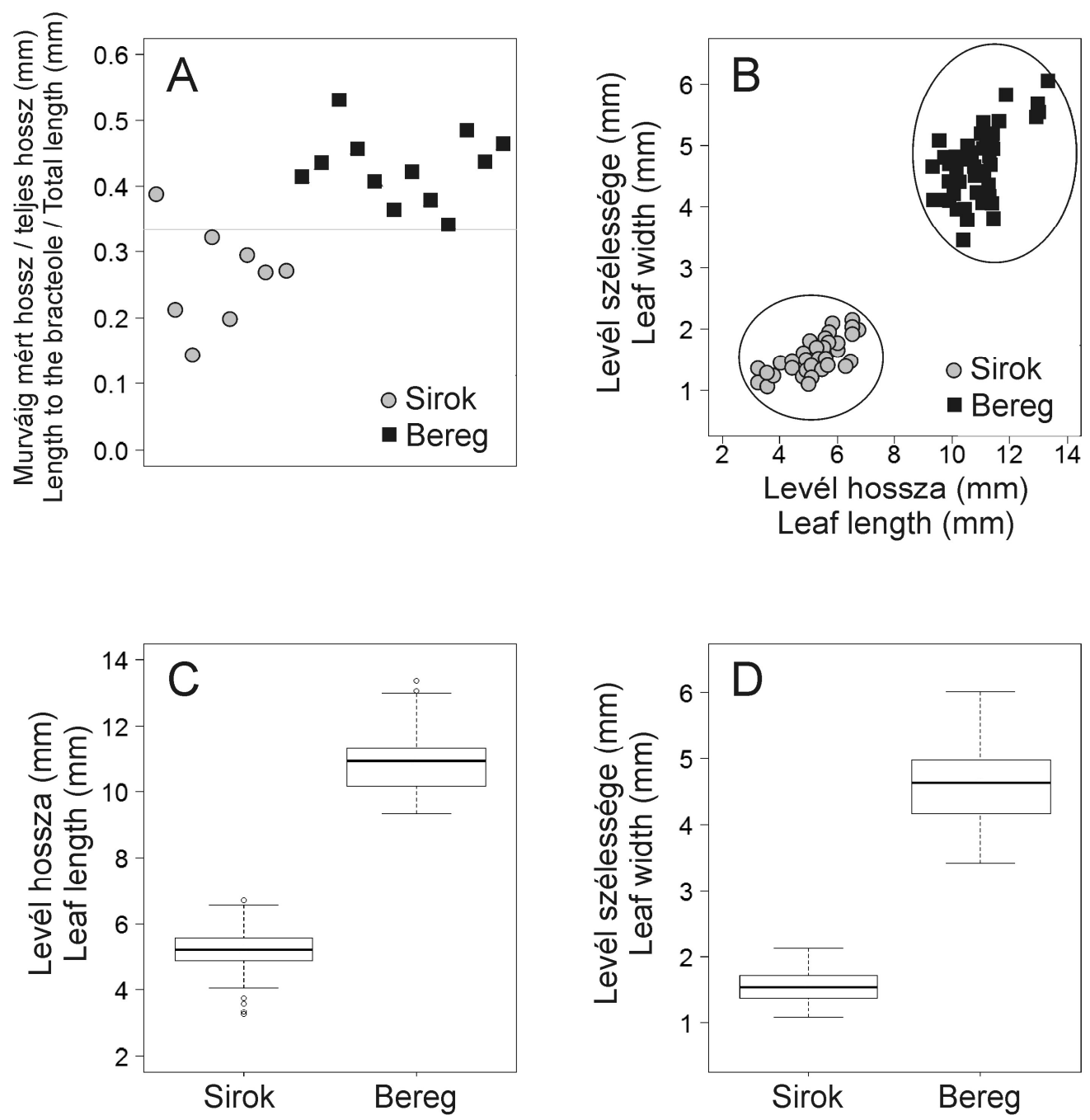

1. ábra. A két vizsgált állomány néhány alaktani jellemzőjének összehasonlítása.

A - a murvalevél pozíciója; $\mathrm{B}$ - a levéllemez mérete; $\mathrm{C}$ - a lomblevél hossza; D - a lomblevél szélessége

Fig. 1. Comparison of some morphological features of the examined populations. A - position of bracteole; B - size of leaf; C - length of leaf; D - width of leaf 
A Vaccinium microcarpum azokban a szomszédos államokban, ahol előfordul, mindenütt védett faj, IUCN besorolását tekintve súlyosan veszélyeztetett (CR) (JAKAB et al. 2007, KRICSFALUSY \& BUDNIKOV 2007, TURIS et al. 2014, [1], [2], [3]). Jelenléte a siroki Nyírjes-tó lápján valószínűleg emberi betelepítés eredménye, azaz őshonossága nem valószínű. Erre utal, hogy egyszerre került elő az addig a területről szintén ismeretlen Drosera rotundifoliaval és 1994 előtti jelenlétére nincs semmilyen bizonyíték. Ugyanakkor a spontán betelepülés (zoochoria) sem zárható ki teljesen, azonban ennek esélyét minimálisnak gondoljuk elsősorban a legközelebbi populációk nagy távolsága miatt.

\section{Vaccinium microcarpum}

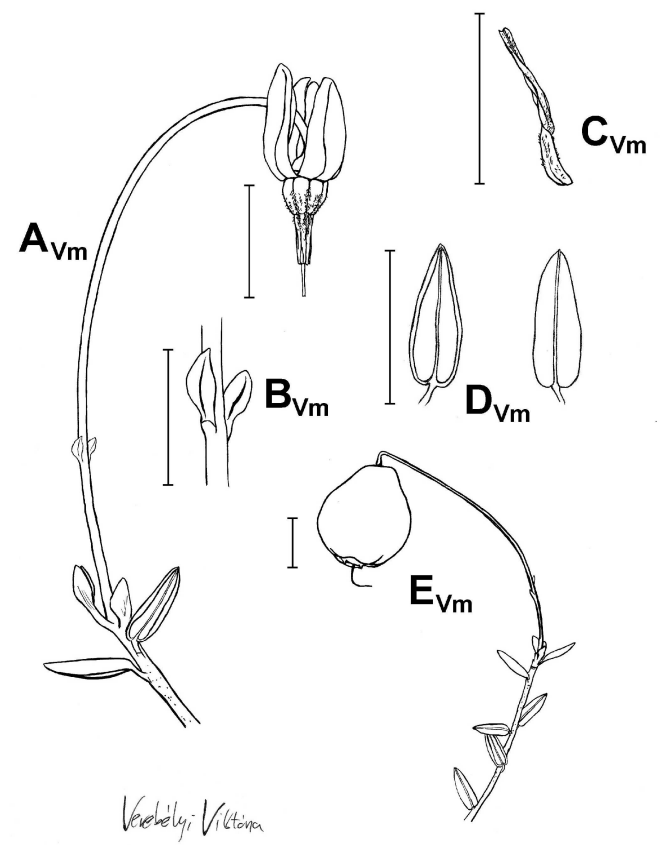

Vaccinium oxycoccos

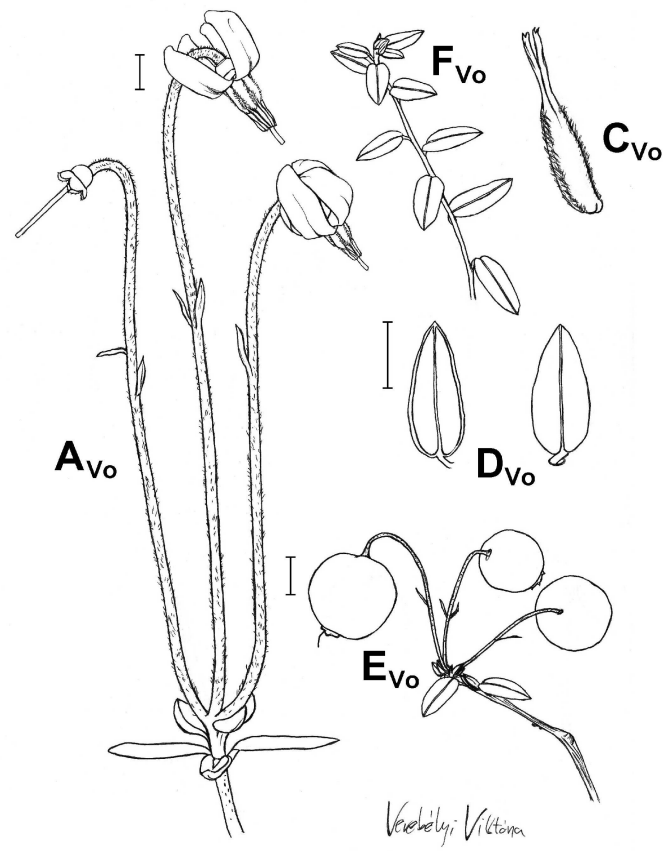

2. ábra. A két vizsgált faj összehasonlítása (Verebélyi Viktória eredeti rajzai). A: virágzat; B: murvalevelek; C: porzó; D: levél abaxiális és adaxiális nézetben; E: terméses kocsány; F: leveles hajtás Fig. 2. Comparison of the two studied taxa (original drawings of Viktória Verebélyi). A: inflorescence; B: bracteoles; C: anther; D: abaxial and adaxial side of leaf; E: pedicel with fruit; F: vegetative shoot

\section{Irodalom}

BARTHA D. (1999): Magyarország fa- és cserjefajai. - Mezőgazda Kiadó, Budapest, p. 276.

EскенART J.J. (ed.) (2009): Rothmaler - Exkursionsflora von Deutschland, Bd. 3: Gefäßpflanzen. Atlasband, p. 218.

FARKAS S. (szerk.) (1999): Magyarország védett növényei. - Mezőgazda Kiadó, Budapest, p. 221.

JACQUEMART A-L. (1997): Vaccinium oxycoccos L. (Oxycoccus palustris Pers.) and Vaccinium microcarpum (Turcz. ex Rupr.) Schmalh. (Oxycoccus microcarpus Turcz. ex Rupr.). - Journal of Ecology 85: 381-396.

JAKAB G. \& SÜMEGI P. (2010): Preliminary data on the bog surface wetness from the Sirok Nyírjes-tó peat bog, Mátra Mts, Hungary. - Central European Geology 53 (1): 43-65.

JAKAB G., CSERGő A.-M. \& AMBRUS L. (2007): Adatok a Székelyföld (Románia) flórájának ismeretéhez I. - Flora Pannonica 5: 135-165

JávoRKa S. (1924-1925): Magyar Flóra. - Studium, Budapest, p. 798.

KRASNOBOROVA I.M. (2000): Opredelitel' rastenij Novosibirskoj oblasti. - Novoszibirszk: Nauka. 
KRICSFALUSY V. \& BudNiKOV G. (2007): Threatened vascular plants in the Ukrainian Carpathians: current status, distribution and conservation. - Thaiszia 17: 11-32.

LÁJER K. (1998): Bevezetés a magyarországi lápok vegetáció-ökológiájába. - Tilia 6: 84-238.

LÁJER K. (2009): Vaccinium L. - In: KIRÁLY G. (szerk.), Új magyar füvészkönyv. Magyarország hajtásos növényei. Határozókulcsok. Aggteleki Nemzeti Park Igazgatóság, Jósvafő, p. 322.

MÁTHÉ I. \& KovÁcs M. (1958): A Mátra tőzegmohás lápja. - Botanikai Közlemények 47: 323-331.

Molnár V. A. (2007): Magyarország legszebb növényei. - Anno Kiadó, Budapest, p. 48.

MoLnÁr V. A. (2008): Tőzegáfonya. - Élet és tudomány 63 (3): 1054 + hátlap.

Popova T.N. (1972): Vaccinium L. - In: Tutin T.G., HeYwood V.H., Burges N.A., Moore D.M., Valentine D.H., Walters S.M., \& WebB D.A. (eds), Flora Europaea. Vol. 3., Cambridge University Press, Cambridge, pp. 12-13.

Simon T. (1953): Torfmoore im Norden des Ungarischen Tieflandes. - Acta Biologica Hungarica 4: 249-252.

SIMON T. (1954): Montán elemek az Északi-Alföld flórájában és növénytakarójában III. (Les éléments montagnards dans la flore et végétation de 1'Alföld septentrional. III). - Ann. Biol. Univ. Hung. 2: 279-286.

Simon T. (1960): Die Vegetation der Moore in den Naturschutz-gebieten des Nördlichen Alföld. - Acta Botanica Hungarica 6: 107-137.

Simon T. (2000): A magyarországi edényes flóra határozója. Harasztok-virágos növények. - Nemzeti Tankönyvkiadó, Budapest, p. 578.

SUDA J. \& LYSÁK M. (2001): A taxonomic study of the Vaccinium sect. Oxycoccus (Hill) W.D.J. Kock (Ericaceae) in the Czech Republic and adjacent territories. - Folia Geobotanica 36: 303-320.

SZMORAD F. \& BARABÁs S. (1999): Tőzegáfonya - Vaccinium oxicoccos L. - Tilia 7: 69-77.

SzURDOKI E. (2005): Magyarországi tőzegmohák elterjedése és egyes fajok vízkémiai igényének vizsgálata. - Doktori értekezés. Eötvös Loránd Tudomány Egyetem, Biológiai Doktori Iskola, $140 \mathrm{pp}$.

Turis P., Kliment J., Feráková V., DítĚ D., Eliáš P., HrivnáK R., KoŠŤÁL J., Šuvada R., Mráz P. \& Bernátová D. (2014): Red List of vascular plants of the Carpathian part of Slovakia. - Thaiszia 24: 35-87.

\section{Hivatkozott világháló oldalak:}

[1] The Annotated Ramsar List of Wetlands of International Importance http://ramsar.rgis.ch/cda/es/ramsar-documents-list-anno-austria/main/ramsar/1-31218\%5E16730_4000_2__(Hozzáférés: 2017. 01.04.)

[2] Portale Sulla Flora del Parco Nazionale del Triglav (Slovenia) http://dryades.units.it/triglav_ita/index.php?procedure=taxon (Hozzáférés: 2017. 01. 04.)

[3] Schede di Botanica. http://luirig.altervista.org/flora/taxa/index1.php?scientificname=vaccinium+microcarpum (Hozzáférés: 2017. 01. 04.)

Beérkezett: 2016. 11. 04. • Elfogadva: 2017. 02. 22. 